\title{
ARTIGO
}

\section{Eu quero imagens, cadê as imagens,} comandante Hamilton? A retórica do populismo penal contemporâneo e a 'democracia da desconfiança', uma análise dos impactos do populismo penal no contemporâneo complexo punitivo

\author{
Leonardo Faustino Pereira ${ }^{1}$ | Sara Carolina Zica Ribeiro ${ }^{2}$
}

Como citar este artigo: PEREIRA, Leonardo Faustino; RIBEIRO, Sara Carolina Zica. Eu quero imagens, cadê as imagens, comandante Hamilton? A retórica do populismo penal contemporâneo e a 'democracia da desconfiança', uma análise dos impactos do populismo penal no contemporâneo complexo punitivo. Revista de Ciências do Estado. Belo Horizonte: v. 5, n. 1, e15166. ISSN: 2525-8036.

Resumo: o complexo punitivo brasileiro, esse aqui compreendido não apenas como a prisão mas sim como todas as instâncias de exercício do poder estatal em sua atividade criminalizadora, não existe apenas na figura de seus agentes, instituições e meios físicos de controle e contenção, mas também possui existência no campo cultural, infiltrando-se na linguagem e, através dessa, na percepção social da realidade. Dessa forma, é possível se falar que existe uma linguagem punitiva formada, e capaz de reformar, o complexo punitivo. No entanto, essa linguagem, existindo como um constructo social, está continuamente à mercê de fatores externos, sendo que o recente escalonamento da sectarização ideológico-partidária e o aparecimento de identidades políticas baseadas na desconfiança nas instituições tradicionais, remodelaram essa linguagem e, em última instância todo o complexo punitivo, em direção a um ultrapunitivismo de forte apelo populista. $\mathrm{O}$ presente artigo tenta compreender como as contemporâneas relações entre política e linguagem acabaram levando a esse fenômeno.

Palavras-chave: crime; populismos; linguagem.

\footnotetext{
${ }^{1}$ Mestrando em Direito pela Universidade Federal de Minas Gerais. Bacharel em Direito pela Universidade Federal de Minas Gerais. E-mail: leonardopereira.faustino@hotmail.com. Orcid: https://orcid.org/0000-00020100-2425.

${ }^{2}$ Especialista em Direito Processual Civil e Direito de Família e Sucessões pelo Centro de Atualização em Direito. Bacharel em Direito pela Universidade Federal de Minas Gerais. E-mail: saraczribeiro@gmail.com. Orcid: https://orcid.org/0000-0003-2039-1611.
} 
Aprovado em 29.04.2020

Publicado em 13.05.2020

\section{INTRODUÇÃO}

Uma das figuras que ganha cada vez mais voz e relevância no espaço discursivo público em temas relativos à segurança pública é o jornalismo policial popular. Muitas vezes apresentados por um único repórter, que fala de modo passional e informal diretamente com a câmera descrevendo em detalhes imagéticos o crime ou fazendo longas defesas quanto aos “direitos das vítimas” e a malignidade das ações de seus algozes, esses telejornalísticos podem ser apontados como representantes, senão mesmo avatares, de uma linguagem punitiva que se tornou cotidiana nos debates nacionais, sejam esses da sociedade civil ou mesmo dos órgãos institucionais. Na verdade, pode-se dizer, inclusive, que essa nova linguagem representa em grande parte os problemas e desafios do complexo punitivo pátrio hodierno. Citando KLEMPERER (2013, p.10): “pois assim como é costume falar do rosto de uma idade ou de um país, por isso também é usual caracterizar o espírito de uma época particular como sua língua"3. Essa nova linguagem tem como sua principal função acalmar os medos e ansiedades do público/eleitorado indicando aos mesmos quais devem ser os alvos de seus medos e apreensões, enquanto reforça a confiança em símbolos/instituições de poder e ordem institucionais. No entanto, essa mesma linguagem dialeticamente também reforça essas mesmas apreensões coletivas, atacando a "brandura" desses símbolos/instituições de controle e sempre recomendando um recrudescimento punitivista, em um esforço de mobilização midiático/política, muitas vezes com objetivos alheios ao próprio sistema penal.

Este estudo defende a ideia de que essa nova "língua punitiva" imagética, de expressivo apelo empático e, fundamentalmente, baseada na dissidência e desconfiança dos meios tradicionais de resolução de conflitos, é algo que atualmente está presente não apenas nos cotidianos telejornalísticos policialescos e nos tabloides sensacionalistas mas também, em uma versão ligeiramente mais "culta", no discurso institucional dos órgãos e agentes de segurança pública. Tendo isso em conta, o presente trabalho tem como objetivo compreender a infiltração dessa nova "linguagem punitiva" e o contexto do seu desenvolvimento recente, através da análise dos discursos inaugurais de três figuras políticas fundamentais para a compreensão do recrudescimento do discurso punitivo recente: o presidente Jair Messias

\footnotetext{
${ }^{3}$ Traduzido livremente do original: “(...)For just as it is customary to speak of the face of an age or of a country, so it is also usual to characterize the spirit of a particular epoch as its language.(...)".
} 
Bolsonaro; o ex-ministro da Justiça e Segurança Pública Sérgio Fernando Moro; e o governador do Estado do Rio de Janeiro Wilson José Witzel.

Para além do puro proselitismo político, é importante perceber que os primeiros discursos e falas de um agente públicos ligados ao executivo, particularmente presidentes, ao alçar o poder são muito importantes para a compreensão das políticas e do modus operandi de seu futuro governo ${ }^{4}$. A análise desses discursos, então, mostra-se fundamental para a compreensão dessa "nova língua punitiva", e, assim, vislumbrar um pouco melhor o atual estado e mentalidade do complexo punitivo nacional, uma vez que, citando novamente KLEMPERER (2013, p.11):

Seja o que for que as pessoas estejam determinadas a esconder, seja apenas dos outros, ou de si mesmas, até mesmo coisas que carregam inconscientemente - a linguagem revela tudo. Isso é sem dúvida o significado do aforismo Le style c'est l'homme; o que um homem diz pode ser um pacote de mentiras - mas seu verdadeiro eu é posto a nu para todos verem no estilo de suas declarações ${ }^{5}$.

Dessa forma, o presente estudo desenvolverá a análise dos discursos preambulares das três personalidades públicas citadas, analisando também, embora de forma breve, suas biografias e a conjuntura que fundamenta a relevância das mesmas no cenário político contemporâneo. Isso, não apenas porque se entende aqui que o discurso é um constructo social e, portanto, extremamente dependente de seu contexto de origem, mas também porque a compreensão da natureza altamente polarizadora dessas personas e os efeitos dessa polarização nas instituições republicanas atuais é essencial para o entendimento da origem da nova "linguagem punitiva" objeto desse estudo.

\footnotetext{
4 "Inaugural presidential addresses have a special significance in a country's political history. They are solemn public occasions in which the newly invested presidente addresses the people and their representatives for the fi rst time as head of state and head of government. He/she speaks to the citizens and to his/her own voters. He/ she also speak to a wider audience of foreign guests and domestic and international powerbrokers and economic actors. It is an occasion in which the new presidente has to navigate a narrow path between being 'above politics' in his/her condition as head of state representing all the people and being head of a new government elected with a political mandate. It off ers the new president an unparalleled platform to present him/herself in their new role, reflect on the circumstances of his/her election and outline his/her vision of the country's history and future". (PANIZZA, 2016, p. 200)

${ }^{5}$ Traduzido livremente do original: “(...)Whatever it is that people are determined to hide, be it only from others, or from themselves, even things they carry around unconsciously - language reveals all. That is no doubt the meaning of the aphorism Le style c'est l'homme; what a man says may be a pack of lies - but his true self is laid bare for all to see in the style of his utterances.(...)"
} 


\section{2 'TEM QUE MUDAR TUDO ISSO QUE TÁ AI, OK?': CONTINUIDADE E}

\section{RUPTURA, A DESCONFIANÇA COMO BASE DA IDENTIDADE POLÍTICA CONTEMPORÂNEA}

Uma das frases mais conhecidas do atual chefe de Estado brasileiro é a frase: "tem que mudar tudo isso que tá ai” (sic). Embora inicialmente ela possa parecer apenas uma frase de efeito comum, ela denota um claro desejo, seja do próprio presidente seja de sua base política, por uma mudança estrutural da forma como as instituições funcionam (ou ao menos como essas são percebidas pela parcela do público a qual a fala é dirigida). Essa citação, em grande parte resume a tônica de seus primeiros discursos no cargo, onde seu novo governo se apresenta como uma mudança em relação aos governos passados, apresentados como uma ameaça à unidade nacional. ${ }^{6}$

Nesse ponto, é interessante ao presente trabalho analisar brevemente a biografia do presidente e do contexto de seu entorno. Até pouco antes de sua eleição em 2018 como chefe do executivo, Jair Messias Bolsonaro não era uma figura política proeminente. Após ter saído do exército em 1987, Bolsonaro iniciou sua carreira política como vereador na Câmara Municipal do Rio de Janeiro entre 1988 e 1990, posteriormente se elegendo como deputado estadual de 1991 até 2018, sempre com uma plataforma política conservadora e com várias pautas envolvendo os militares e questões de costumes. Entretanto, durante a maior parte desse período ele foi relativamente pouco conhecido, ganhando alguma notoriedade a partir das Jornadas de Junho de 2013 em que, conforme notado por SILVA (2019), ele estrategicamente passou a se vincular sua imagem através das redes sociais a uma ideia antiestablishment. Imagem essa, que a despeito de ter lhe angariado uma fama de personagem anedótico, lhe permitiu se descolar do sentimento de descontentamento com a classe política durante as eleições de 2018.

HUNTER e POWER (2019) notam, que a ascensão política meteórica de Bolsonaro em 2018 se deu primordialmente por aquilo que os autores chamaram de The perfect Storm. Uma conflagração de crises políticas, decorrentes do enfraquecimento do PT e de outros partidos tradicionais por causa de escândalos envolvendo corrupção, e de uma persistente crise econômica que criaram um cenário político em que o eleitorado estava em busca de opções fora do establishment. Um cenário perfeito para um outsider como Jair Messias Bolsonaro. "Bolsonaro foi o único candidato que estava do lado certo de ambos os recortes.

\footnotetext{
6 Nesse ponto, é interessante visualizarmos os seguintes trecho do discurso presidencial pós eleição, disponibilizado em versão escrita pelo Correio Brasiliense no dia 28 de outubro de 2018: "orações de homens, mulheres, crianças, famílias inteiras que, diante da ameaça de seguirmos por um caminho que não é o que os brasileiros desejam e merecem, colocaram o Brasil, nosso amado Brasil, acima de tudo" (grifos nossos).
} 
Ele combinava com os eleitores que detestavam o PT, e combinava com os eleitores que odiavam todo mundo"7 (HUNTER; POWER, 2009, p. 80).

É importante notar, entretanto, que mesmo eleito ele não perdeu a tônica de luta contra o status quo presente em seu discurso de campanha. Mesmo uma análise superficial dos primeiros discursos do presidente Jair Bolsonaro no poder, já permitem perceber a frequência de alguns termos em suas falas que revelam a utilização de uma retórica populista voltada a criar um laço de proximidade com uma parcela de sua base eleitoral ${ }^{8}$. Palavras como "mudança", "verdade", "liberdade" e "reconstrução" são constantes em suas falas e, junto com uma contínua menção de temas de cunho religioso, moral e mesmo "ideológico", apontam a construção de uma identidade tanto do governo como de uma parcela de seu eleitorado, baseada na desconfiança dos mecanismos institucionais e políticos tradicionais e na crença pela necessidade de uma renovação moral da sociedade.

\begin{abstract}
Esse momento não tem preço. Servir à Pátria como chefe do Executivo. E isso só está sendo possível porque Deus preservou a minha vida. E vocês acreditaram em mim. Juntos temos como fazer o Brasil ocupar o lugar de destaque que ele merece no mundo e trazer paz e prosperidade para o nosso povo.

É com humildade e honra que me dirijo a todos vocês como Presidente do Brasil. E me coloco diante de toda a nação, neste dia, como o dia em que o povo começou a se libertar do socialismo, se libertar da inversão de valores, do gigantismo estatal e do politicamente correto.

As eleições deram voz a quem não era ouvido. E a voz das ruas e das urnas foi muito clara. E eu estou aqui para responder e, mais uma vez, me comprometer com esse desejo de mudança. Também estou aqui para renovar nossas esperanças e lembrar que, se trabalharmos juntos, essa mudança será possível. (Discurso do presidente da república, Jair Bolsonaro, durante cerimônia de recebimento da faixa, 2019)
\end{abstract}

\footnotetext{
${ }^{7}$ Traduzido livremente do original: Bolsonaro was the only candidate who was on the right side of both cleavages. He energized voters who detested the PT, and he energized voters who detested everyone.

8 "While the dichotomisation of the political space is central to the definition of populism it is not what populism is about: populism is about the construction of popular identities. In this definition the identity of both 'the people' and its 'other' are political constructs rather than sociological categories (PANIZZA, 2005a, p. 3). Paraphrasing Michael KAZIN (1998), populism can be understood as a mode of political identification that is available to any political actor operating in politico-discursive field in which the notion of sovereignty of the people and its inevitable corollary, the confl ict between the powerful and the powerless, are core elements of its political imaginary (PANIZZA, 2005, p. 4). The very way in which the identity of the people is constructed opens up a political frntier that tends to divide society into two irreconcilable camps (LACLAU 2005, p. 38; PERUZZOTTI 2013, p. 69). Paraphrasing George CICCARIELLO-MAHER (2013), quoted in Spanakos 2013, 4) in his study of the construction of popular identities in Chávez's Venezuela, populismo constructs the people as a category of both rupture and struggle, a moment of combat in which those oppressed within the prevailing political order or excluded from it intervene to transform the system, in which a victimised part of the community speaks for and attempts to radically change the whole. In other words, the plebs aspire to become the demos, that is, the holders of sovereignty." (PANIZZA, 2016, p. 196).

${ }^{9}$ É interessante, nesse ponto, visualizarmos a seguinte fala do presidente Jair Bolsonaro em seu discurso de posse no Palácio do Planalto ao receber a faixa presidencial: "não podemos deixar que ideologias nefastas venham a dividir os brasileiros. Ideologias que destroem nossos valores e tradições, destroem nossas famílias, alicerce da nossa sociedade" (Discurso do presidente da república, Jair Bolsonaro, durante cerimônia de recebimento da faixa, 2019)
} 
Perceba-se, contudo, que esse texto não se aventura a designar o presente governo como populista em seu todo, apenas afirmando que o mesmo se utiliza de táticas populistas de forma pontual para alcançar seus objetivos, como ficará mais claro adiante quando desenvolvermos a argumentação a respeito do populismo penal na área da segurança pública. Por hora, entretanto, é importante mencionar para os objetivos do presente trabalho, que o populismo, seja como mera estratégia de retórica seja como linha guia para governo, possui como uma de suas características mais básicas a disseminação da dissidência e sectarismo. Segundo PRATT (2007), mais do que plataformas e discursos políticos flutuantes e ao sabor da opinião pública, populistas normalmente escolhem um certo setor da sociedade descontente com algum aspecto do status quo e de alguma forma alienados dele. Impondo-se como porta vozes desses grupos de alguma forma marginalizados no jogo político cotidiano, os populistas logo elegem antagonistas baseados nos medos e desejos do grupo ao qual passa a representar. É importante apontar que embora PANIZZA (2016) reconheça o sectarismo como uma das questões centrais do populismo, ele designa como a questão mais central do fenômeno a construção de laços de identidade entre agentes políticos e parcelas da sociedade baseadas exatamente na sectarização citada. Essa última perspectiva é particularmente interessante para o presente trabalho, uma vez que se defende que é justamente a construção de uma identidade política baseada na dicotomização da sociedade entre "nós" e "eles" (o inimigo) que acirra a desconfiança já pré-existente nas relações entre Estado-cidadão no Brasil.

É importante se perceber, contudo, que a desconfiança estrutural quanto às instituições democráticas não é algo novo para a realidade brasileira ${ }^{10}$. Em pesquisa realizada pelo World Values Survey entre janeiro e outubro de 2014, verificou-se que o nível de confiança dos entrevistados brasileiros em instituições políticas como partidos ou o parlamento eram alguns dos menores em meio a todos os países entrevistados. Por exemplo, o número de pessoas que declararam não possuir nenhuma confiança no parlamento foi o segundo maior de todos os países entrevistados, perdendo apenas para a Tunísia. MOISÉS e

\footnotetext{
10 "A democracia brasileira está relativamente consolidada - a maior parte dos especialistas reconhece isso. Mas ela enfrenta uma situação paradoxal: apesar de o apoio ao regime democrático per se ser majoritário, quase dois terços dos brasileiros não confiam - em diferentes graus - em parlamentos, partidos, governos, tribunais de justiça, polícia e serviços de saúde e educação. Surveys realizados por Moisés em 1989, 1990 e 1993 revelaram que a percepção negativa que se tem das instituições atravessa todos os segmentos de renda, escolaridade, idade e distribuição ecológica, chegando a influir na disposição dos cidadãos em participar de processos de escolha de governos. Além disso, esses surveys também mostraram que é grande a insatisfação com o funcionamento concreto da democracia (Moisés, 1995). Resultados semelhantes foram encontrados ainda por um survey realizado em 2006, sob a coordenação de Moisés e Meneguello (MOISÉS, 2006).” (MOISÉS e CARNEIRO, 2010, p. 150).
} 
CARNEIRO (2010), comentando sobre resultados semelhantes, não puderam deixar de notar uma relação entre altos níveis de desconfiança entre a população e a aceitação de medidas de cunho autoritário e antidemocrático.

ROSAVALLON (2008) cunhou o termo counter democracy [ver no original francês de 2006, "Contre-Démocratie"] para explicar um contínuo movimento de suspeita e desconfiança institucional que existe em uma reação dialética com (e em) todos os regimes democráticos. No entanto, embora a desconfiança e suspeita possam ser necessárias e mesmo saudáveis para a existência de uma democracia, seu excesso é bastante perigoso. Particularmente quando acompanhado pelo fenômeno de despolitização social, não compreendido por ROSAVALLON (2008) como a perda do interesse da sociedade pela política, mas sim de um afastamento entre a sociedade e as instituições públicas ${ }^{11}$ :

A recente tendência à desintegração política tem duas causas. A lacuna que os counter powers tendem a se abrir entre a sociedade cívico-civil e a esfera política é uma. Por razões funcionais, os counter powers tendem a se distanciar das instituições oficiais: a prova de sua eficácia está em sua capacidade de enfraquecer os poderes. $\mathrm{O}$ cidadão-como cão de guarda ganha o que o cidadão-eleitor perde; o soberano negativo se afirma às custas do soberano tout court; a organização da desconfiança enfraquece a suposição de confiança conferida pela eleição. Por razões estruturais, portanto, a esfera política tende a se alienar da sociedade, a situar-se externamente. Assim, quando os cidadãos reivindicam counter powers, os poderes legais são desvalorizados e minimizados. Como consequência lógica da descontinuidade que se estabelece entre a sociedade e as instituições do governo, o estadista é automaticamente rebaixado ao posto de "político". Para ser mais direto, a democracia restringe a democracia: os funcionários eleitos são controlados e perdem espaço para manobra devido à pressão dos próprios eleitores. Como resultado, a dinâmica de controle tem precedência sobre a apropriação de poder. $\mathrm{O}$ cidadão é transformado em um consumidor político cada vez mais exigente, renunciando tacitamente à responsabilidade conjunta de criar um mundo compartilhado. É enganoso, no entanto, interpretar este desenvolvimento como nada mais do que um sinal de retorno para a vida privada ou de crescente indiferença ao bem-estar dos outros, pontos repetidos incessantemente por uma literatura crítica dos estragos do individualismo democrático e repleta de alegações de uma impotência pública "diante do poder inexoravelmente crescente do setor privado. Pelo contrário, a "era do consumismo político" tem sido caracterizada por altas expectativas de instituições políticas e demandas crescentes sobre elas. O problema decorre do modo como essas demandas são expressas, o que tende a deslegitimar os poderes aos quais

11 "If what we are witnessing is not depoliticization, in the sense of diminished interest in public affairs and declining citizen activity, it remains true that something has indeed changed in our relation to the political. The nature of this change is different from what is usually suggested, however. The problem today is not one of citizen passivity but rather of what I shall call l'impolitique, the unpolitical, by which I mean a failure to develop a comprehensive understanding of problems associated with the organization of a shared world. The distinguishing characteristic common to the various examples of counter-democracy that we shall be examining is the increase in the distance between civil society and institutions. In each instance we find a sort of counterpolicy, which relies on monitoring, opposition, and limitation of government powers, the conquest of which is no longer the top priority of government opponents. Counter-policy manifests itself in two ways. The initial consequence of counter-political strategies and actions is to dissolve signs of a shared world. Reactive in essence, these strategies and actions cannot sustain or structure collective projects. The distinctive feature of this sort of unpolitical counter-democracy is that it combines democratic activity with non-political effects. Hence it does not fall within the usual classification of regime types; it is a novel type, neither liberal nor republican, neither representative government nor direct democracy." (ROSAVALLON, 2008, p. 22). 
elas são dirigidas. Esta é a fonte do desencanto contemporâneo com a democracia. Desapontamento é uma consequência quase inevitável de uma cidadania desconfiada. (ROSAVALLON, 2008, p. 253-254). ${ }^{12}$

Dessa forma, começa a se tornar cada vez mais evidente, a construção no Brasil contemporâneo de uma técnica discursiva, uma verdadeira narrativa identitária, que acirra a desconfiança estrutural nas instituições políticas.

\section{O SUPERMINISTÉRIO DA JUSTIÇA: DESCONFIANÇA, MEDO E} RECRUDESCIMENTO PUNITIVO

Se, por um lado se deixou claro que existe uma relação entre a retórica do presente governo e o aumento da percepção social estrutural de uma insegurança quanto às instituições políticas, neste ponto é importante traçarmos a relação dessa última com o recrudescimento das leis penais e das políticas de segurança pública. Antes de mais nada, é importante acentuar que a percepção social do crime (também chamada de medo do crime), mais do que apenas ser movida pelo objetivo temor que os indivíduos sentem de ser vítimas de uma ação criminosa, é também incitada por um caldeirão de medos e ansiedades subjetivas pouco ou nada relacionadas ao evento criminógeno.

Dizendo de forma mais clara, o medo não é apenas uma expressão da preocupação individual de uma possível vitimização, mas é também uma forma de expressão de abstratas ansiedades e frustrações sociais. Um bom exemplo disso pode ser percebido a partir dos estudos de FURSTENBERG (1971). Esse último, ao pesquisar sobre os impactos que a integração racial durante os anos dos movimentos pelos direitos civis tinha sobre a percepção

12 Traduzido de forma livre do trecho: "The recent tendency toward political disintegration has two causes. The gap that counter-powers tend to open up between civic-civil society and the political sphere is one. For functional reasons, counter-powers tend to distance themselves from official institutions: the proof of their efficacy lies in their ability to weaken the powers-that-be. The citizen-aswatchdog gains what the citizen-as-voter loses; the negative sovereign asserts himself at the expense of the sovereign tout court; the organization of distrust undermines the assumption of trust conferred by election. For structural reasons, therefore, the political sphere tends to become alienated from society, to situate itself externally. Thus when citizens claim counterpowers, legal powers are devalued and minimized. As a logical consequence of the discontinuity that is established between society and the institutions of government, the statesman is automatically degraded to the rank of "politician." To put it more bluntly still, democracy restricts democracy: elected officials are reined in and lose their room to maneuver owing to pressure from the voters themselves. As a result, the dynamics of control take precedence over the appropriation of power. The citizen is transformed into an ever more demanding political consumer, tacitly renouncing joint responsibility for creating a shared world. It is misleading, however, to interpret this development as nothing more than a sign of retreat into private life or growing indifference to the welfare of others, points repeated incessantly by a literature critical of the ravages of democratic individualism and filled with allegations of public "impotence" in the face of the inexorably increasing power of the private sector. On the contrary, the "age of political consumerism" has been characterized by high expectations of political institutions and growing demands upon them. The problem stems from the way in which these demands are expressed, which tends to delegitimate the powers to which they are addressed. This is the source of the contemporary disenchantment with democracy. Disappointment is an almost inevitable consequence of a distrustful citizenry". 
social da criminalidade, chegou à conclusão de que a apreensão e ansiedade causadas por mudanças sociais de caráter geral causavam um amento da percepção de vulnerabilidade ao crime e insegurança sobre a parcela mais conservadora da população ${ }^{13}$. Extrapolando um pouco a hipótese de FURSTENBERG (1971), JACKSON (2006) apresenta a ideia de que o medo do crime é uma válvula comum de escape para todas as ansiedades e medos sociais, mesmo aqueles não vinculados necessariamente à uma mudança social ${ }^{14}$. Na mesma linha, PLEYSIER E COPS (2016) ao estudarem a percepção do crime em adolescentes, chegaram à conclusão que o medo do crime funciona como uma espécie de "esponja'15 para outras apreensões e ansiedades modernas, particularmente para os grupos que se sentem inseguros de seu lugar na hierarquia social. Citando JACKSON (2006, p.11) "O medo do crime pode, portanto, ser tanto sobre julgamentos de ameaças criminais reais quanto sobre julgamentos de uma série de coisas vistas como ameaçadoras à ordem social"16.

Tendo isso em conta, torna-se evidente que ansiedades e frustrações sociais de caráter estrutural impactam profundamente na construção da percepção social do crime. $\mathrm{Ou}$ seja, quando maior o sentimento de insegurança e ansiedade, maior será a percepção social de vulnerabilidade ao evento criminógeno e, portanto, maior será o clamor sócio-político por leis

13 Nesse ponto, FURSTENBERG (1971) traça uma curiosa análise quanto à relação entre o aumento da percepção do crime e as mudanças das relações raciais dos EUA da década de 1970: "the area of social change that aroused the greatest opposition was racial integration. Apparently resentment toward efforts to improve the situation of blacks sparked much of the opposition to change in general. Nearly a third of the whites felt that Negroes had been demanding more than they were ready for, and belived that their attempts to gain equality should be slowed down. Another third held one or the other of these views, and only one-fifth rejected both statements. Concern about crime was highest among whites most antagonistic to racial reform (forty-two percent) and lowest among the strong supporters of racial equality (thirteen percent). Thus, our findings generally support the view that concern about crime is at least in part an expression of resentment of changing social conditions, especially efforts to eliminate racial injustice". (FURSTENBERG, 1971, 606).

14 Segundo JACKSON (2006, p.11): “(...) Fear of crime may operate as a 'sponge', absorbing all sorts of anxieties about related issues of deteriorating moral frabric, from family to community to society. People may use the language of 'worry' and 'crime' to express connecting conflitcs, insecurities and anxieties. From such perspective, the fear of crime expresses complex and subtle lay understings of the social world - about the nature and make-up of society and the value placed on crime in this symbol of deterioration. Data from crime surveys may reflect everday experience of fear, and the possession of a vivid image of the risk event. But data also reflect a more generalized and expressive attitude toward social cohesion and moral consensus (JACKSON, 2004b)."

15 "In other words, the extent to which the fear of crime operates as a 'sponge,' absorbing more generalized feelings of insecurity and uncertainty, is a product of a developmental and dynamic process and can therefore be seen as more prominent and pronounced in the unstable transition from adolescence to adulthood, compared to adulthood itself. In fact, our previous study (COPS et al., 2012) found that these more general anxieties and attitudes have less influence on fear of crime among adolescents compared to young adults, possibly because these more general concepts about society, justice, etc. are not fully developed in adolescence. Similar tendencies could also be identified with regard to the concept of general fear, in which the range of fears of an individual over time moves from concrete events to more abstract, hypothetical and anticipatory situations (GULLONE, 2000)". (PIEYSIER; COPS, 2016, p.11).

${ }^{16}$ Traduzido livremente pelo autor do seguinte trecho: ““Fear of crime may thus be as much about judgments of actual criminal threat as it is about judgments of a range of things seen as threatening to social order". 
e políticas criminais mais draconianas, assim como de líderes e agentes públicos mais afinados com uma perspectiva de Estado mais repressivo.

Não é preciso dizer que "o medo de crime" teve um papel central nas eleições de $2018^{17}$, e no pensamento por trás da formação do governo eleito. É importante lembrar que uma das características mais marcantes no discurso de Bolsonaro, é sua tendência a apresentar soluções violentas, muitas vezes não respeitando garantias processuais básicas, ao problema da criminalidade. A abordagem argumentativa antihumanista que o presidente gosta de usar em temas relativos à segurança pública esbarra, entretanto, em limites institucionais e normativos para os quais a explosiva linguagem de Bolsonaro é mero ruído, sem forma ou relevância. Nesse ponto, a escolha, do agora ex-ministro, Sérgio Fernando Moro para ocupar a cadeira do superministério da justiça e da segurança pública, não poderia ser mais estratégica.

Antes de mais nada, é interessante passarmos brevemente pela biografia e conjuntura que levaram à Moro a ocupar até abril de 2020 o ministério da justiça. Professor da Universidade Federal do Paraná e juiz federal desde 1996, Moro atuou como juiz nos casos Banestado e Operação Farol da Colina. No entanto, o que lhe angariou fama nacional, e é um ponto central para a compreensão dessa persona política, foi sua atuação entre 2014 e 2018 no julgamento do processo que ficou conhecido como Operação Lava a Jato. Os desdobramentos desse julgamento, inclusive, foram centrais para a construção do cenário político que permitiu a subida ao poder de Bolsonaro.

É importante notar, que a percepção quanto ao processo, que em grande parte se confunde com seu antigo julgador que se tornou um símbolo vivo da opinião pública desse julgamento, são mesmo hoje ainda bastante polarizadoras. A despeito de irregularidades como o vazamento de áudios de interceptações telefônicas entre o ex-presidente lula e da presidenta Dilma Rousseuff (que foram um dos fatores culminantes para a crise que levou ao impeachment da última) ou do vazamento do depoimento do Marcelo Odebrecht para o site $\mathrm{O}$ Antagonista, existia um relativo consenso mesmo no campo jurídico sobre a "normalidade" do processo até bem recentemente. Apenas com a publicação das conversas entre Moro e os

17 “ (...) alarming levels of violent crime and public insecurity were pivotal to the outcome of the 2018 campaign. In 2017, seventeen of the fifty most violent cities in the world were in Brazil. The preponderance of these were located in the country's north or northeast and formed part of drug transit routes. In that same year, 63,880 people were murdered in Brazil, up 3 percent from 2016, and the murder rate was 30.8 per 100,000 people-a figure that compares unfavorably even with homicide rates in Mexico. That everyday policing is largely a statelevel responsibility in Brazil's federal system, and not within the purview of presidents except in emergency situations, was an academic point in the minds of most voters. Heightened fear of crime cut across socioeconomic as well as ideological lines, giving Bolsonaro another opportunity to build broad political support. In truth, his hard-line "eye for an eye" discourse, combined with the view that human rights must be subordinated to public safety, was nothing new: Bolsonaro had virtually "owned" this policy space since the 1990s. (HUNTER; POWER, 2019, p. 73). 
procuradores da Lava-Jato pelo jornal The Intercept Brasil, que mostrou de forma bastante clara as intervenções de Moro no andamento do julgamento, se tornou clara a real extensão da manipulação política que ele fez através do processo. A despeito de tais revelações não terem diminuído a maior parte do sentimento social de apoio ao processo e, por extensão, a ele.

Voltando ao tema em análise, a forte vinculação que Sérgio Moro tinha com a Operação Lava-Jato no pensamento coletivo, fez com que o mesmo encarnasse uma espécie de símbolo de ordem para parte considerável da população. Note-se, que existe um forte personalismo na percepção do papel de Moro no citado julgamento. Os méritos do processo são vistos como seus méritos pessoais, não existindo diferença entre ele e o citado processo. Em seu discurso de posse como ministro, ele cita a Operação Lava-Jato e reforça essa confusão, descrevendo o processo em que atuou como juiz como uma espécie de cruzada pessoal contra a corrupção:

Ontem mesmo, verifiquei que o Brasil, apesar da Operação Lava-Jato e dos enormes esforços aqui e ali contra a corrupção, permanece em uma posição relativamente ruim nos índices de percepção quanto à existência de corrupção nos rankings anuais da Transparência Internacional. Entre 180 países, o Brasil ocupa a nonagésima sexta posição. Rigorosamente a pontuação obtida pelo país, $37 \mathrm{em}$ cem pontos possíveis, caiu desde 2014, quando do início da Operação Lava-Jato. Talvez os esforços judiciais, ao revelarem a magnitude da corrupção entre nós, tenham contribuído, paradoxalmente, para elevar a percepção dela, ao invés de, esses esforços, terem chamado a atenção para o quanto nos temos nos dedicado a superá-la.

Isso para mim ilustra uma verdade conhecida. Não se combate a corrupção somente com investigações e condenações eficazes. Elas são relevantes pois não há combate eficaz à corrupção com impunidade e sem riscos de punição para os criminosos.

Mas não são suficientes. São necessárias políticas mais gerais contra a corrupção, com leis que tornem o sistema de Justiça mais eficaz e leis que diminuam incentivos e oportunidades contra a corrupção. Um juiz em Curitiba pouco pode fazer a esse respeito, no âmbito de políticas gerais, mas no governo federal a história pode ser diferente. (Discurso de Sérgio Fernando Moro ao tomar posse como ministro da justiça e segurança pública, 2019).

Através da lei antricrime, ele se oferece como uma alternativa mais sofisticada ao discurso antihumanista de Bolsonaro quanto à solução do problema da segurança pública, sem deixar de apelar, obviamente, para um punitivismo aberto:

Um dos objetivos prioritários será apresentar um projeto de lei anticrime já no início da próxima legislatura e lutar para convencer, com respeito e toda a abertura ao diálogo, os parlamentares. Não haverá aqui a estratégia não muito eficaz de somente elevar penas. Pretende-se, sim, enfrentar os pontos de estrangulamento da legislação penal e processual penal e que impactam a eficácia do Sistema de Justiça Criminal. Propostas simples, mas eficazes, como, entre outros, a previsão de operações policiais disfarçadas para combater o crime, proibição de progressão de regime para membros de organizações criminosas armadas, e o plea bargain para que a Justiça possa resolver rapidamente casos criminais nos quais haja confissão. Pretende-se deixar mais claro na lei, como já decidiu diversas vezes o Plenário do Supremo Tribunal Federal, que, no processo criminal, a regra deve ser a da execução da condenação criminal após o julgamento da segunda instância. Esse foi o mais importante avanço institucional dos últimos anos, legado do saudoso Ministro Teori Zavascki. Pretendemos honrá-lo e igualmente beneficiar toda a população com uma 
Justiça célere, consolidando tal avanço de uma maneira mais clara na lei. Processo sem fim é justiça nenhuma. Pretende-se ainda fortalecer o Tribunal do Júri, prevendo a execução imediata dos veredictos condenatórios, como já decidiu a Primeira Turma do Supremo Tribunal Federal. Esses são alguns exemplos das medidas previstas no projeto em elaboração. (Discurso de Sérgio Fernando Moro ao tomar posse como ministro da justiça e segurança pública, 2019).

No entanto, o combate à corrupção é o cerne de seu discurso, acima mesmo do combate à criminalidade em geral. Uma vez que, vinculado à imagem da Lava-Jato, ele é percebido uma espécie de símbolo do combate à corrupção e, sabendo-se disso, ele capitaliza essa imagem (ao mesmo tempo em que sua existência no governo ocorre exatamente por causa de seu valor simbólico).

Nessa ótica, é importante se perceber o superlativo através do qual o presidente, e boa parte da mídia, chamaram a ele e ao seu ministério. Ao se agregar o prefixo "super" ao ministério justiça, não apenas se deixa claro o aumento de atribuições do mesmo, mas também o desejo político pelo incremento do sistema punitivo. Desejo esse que responde a um clamor social em grande parte alimentado por ansiedades sociais de caráter estrutural. No entanto, esse mesmo clamor tende a se intensificar, uma vez que o aparato de justiça aumenta, literalmente a ponto de se usar o superlativo em seu nome.

Pouco ajuda também, que o ex-ministro da justiça seja uma figura de grande notoriedade no combate à corrupção, até há pouco recorrentemente citado pelos meios de comunicação. Tal persona, acima de qualquer característica própria, personifica várias ansiedades e frustrações estruturais (seja de forma negativa, seja de forma positiva) frente à percepção pública. Esse contínuo contato com um "símbolo contemporâneo", embora possa parecer inicialmente suprir um "desejo social” de certas parcelas da população por justiça, também aumenta a percepção social do crime. Ao mesmo tempo, as recentes notícias sobre o mesmo ministro apontando irregularidades cometidas pelo mesmo no passado, acabam por tornar o presente cenário cada vez mais dramático uma vez que intensificam os laços de desconfiança contra os meios de solução de conflitos tradicionais. A lei, portanto, passa a perder cada vez mais sua legitimidade popular, frente à discursos que exaltam a confiança irrestrita nas ações e juízos de personas vistas pelo público como símbolos de ordem.

Tornam-se, então, cada vez mais socialmente aceitáveis medidas de recrudescimento da legislação criminal como o projeto anticrime, e cada vez menos se discute medidas de ressocialização. Simultaneamente, também se tornam cada vez mais socialmente toleráveis práticas ilegais como o linchamento de suspeitos por crimes, ou mesmo a execução sumária dos mesmos. Dessa forma, se constrói cada vez mais uma identidade política baseada na percepção aguçada do risco de vitimização criminógena e no desejo pelo aumento do aparelho 
e arbítrio punitivo, em outras palavras, se desenvolve e aprimora um populismo voltado exclusivamente ao sistema punitivo, um populismo penal.

\section{4 'A POLÍCIA VAI MIRAR NA CABECINHA E... FOGO': O POPULISMO PENAL TRIUNFANTE, UM PEQUENO ESTUDO DE CASO SOBRE O DISCURSO PUNITIVO NO RIO DE JANEIRO ATUAL}

Wilson José Witzel, o atual governador do Rio de Janeiro, se destacou desde o início de sua campanha eleitoral por possuir um discurso bastante próximo ao do hodierno presidente. Assim como o presidente Bolsonaro, o governador do Rio de Janeiro também desenvolveu uma retórica voltada à mudança e à construção de uma identidade com seu eleitorado baseada em uma agenda de costumes e no desejo de renovação política.

\footnotetext{
O resultado da última eleição simbolizou o grito de milhares de homens e mulheres cansados da traição e dos atos de corrupção que estão tirando de nós o sentimento de esperança por dias melhores para nós e nossos filhos. (Discurso de Wilson Witzel ao ser empossado governador do RJ, 2019)
}

Isso ocorre porque o cenário político nacional de desconfiança quanto ao establishment que foi central para a escolha do ocupante do executivo federal, também ocorreu em menor escala para a escolha dos executivos estaduais. Wilson José Witzel, um exjuiz sem nenhuma experiência política e portador de um discurso truculento, concorreu com dois políticos profissionais, Eduardo Paes e Romário. Frente a um cenário de descrédito com a política tradicional, a escolha mais óbvia foi Witzel. Em parte também, porque era um dos portadores de um dos discursos mais duros quanto ao controle da criminalidade, apresentando paralelos bastante evidentes com o preferido da campanha presidencial, Jair Messias Bolsonaro.

No entanto, um ponto que diferenciou fortemente o discurso do governador Witzel daquele desenvolvido pelo presidente Bolsonaro foi o seu tom quanto à temática da segurança pública. A despeito de ser possível se apontar um certo populismo penal seja do presente governo, seja durante a campanha eleitoral do mesmo (algo que se diga de passagem se tornou comum na integralidade do espectro político ${ }^{18}$ ), as narrativas e propostas construídas

\footnotetext{
${ }^{18}$ Sobre o assunto, é interessante observar o seguinte trecho de Rolin (2006) sobre o populismo penal nos mais diversos partidos políticos: "A mensagem tem sido "captada" pelos agentes políticos que devolvem à população novas promessas de emprego da força e de "punições exemplares". Assim, o Congresso Nacional tem, muito freqüentemente, criado novos tipos penais e apostado no tipo de resposta simbólica com a qual as penas são agravadas. Em 2003, o governo do Presidente Lula enviou ao Congresso um projeto de lei que estabelecia uma reforma na Lei de Execução Penal (LEP), propondo, entre outras medidas, a criação do chamado "Regime Disciplinar Diferenciado" (RDD). A proposta havia sido criada e implementada ilegalmente pelo governo do estado de São Paulo alguns anos antes e permitia o isolamento de um preso considerado especialmente perigoso por até um ano, renovável por mais um. Assim, a medida disciplinar anterior do isolamento por no máximo 30
} 
tiveram alguma ponderação em não afrontar, ao menos não diretamente, garantias e direitos fundamentais. O presente governador do Rio de Janeiro, entretanto, desenvolveu um discurso muito mais direto e exacerbado quanto ao tema, inclusive defendendo a execução sumária de suspeitos de ações criminosas pela polícia em algumas situações ${ }^{19}$.

Nesse ponto, se torna importante distinguir de forma mais sofisticada o populismo penal de sua variante mais genérica. Se essa última é um tipo de fenômeno político que costuma ocorrer em sociedades com um grande nível de tensão social entre suas classes, e se caracteriza por criar uma identidade social baseada no ressentimento social contra o status quo. O populismo penal se basearia no descontentamento de certas parcelas da população, nascido da crença que os criminosos estariam em uma posição social de vantagem podendo se beneficiar às custas de suas vítimas, seja por uma licenciosidade das leis seja pela corrupção dos agentes de segurança pública. Dessa forma, qualquer política pública que não implicasse diretamente uma punição ou desvantagem para aqueles grupos entendidos como criminosos, seria compreendida pela opinião pública como uma ofensa direta à vítima ${ }^{20}$. Citando GARLAND (2001, p.11), "Um jogo político de tudo ou nada é assumido onde o ganho do infrator é a perda da vítima, e ser "para" vítimas automaticamente significa ser duro com os infratores" ${ }^{21}$. Se o populismo lato sensu é um conjunto de técnicas de gerenciamento e construção de identidades sociais a partir do dissenso, o populismo penal se particulariza por gerenciar e criar identificações a partir de dissensos criados pelo medo, senão mesmo pânico social.

Retornando para a análise do discurso punitivo do governador Witzel, é interessante observar que dois dos principais temas discutidos em seu discurso de posse foram exatamente o endurecimento da ação da polícia no combate ao crime organizado, e a importância da sua experiência pessoal como ex-militar e magistrado na missão de pacificar o Rio de Janeiro.

Cidadãos fluminenses, não permitirei a continuidade desse poder paralelo. Ao receber minha carta patente do Corpo de Fuzileiros Navais, eu jurei, perante a nossa

\footnotetext{
dias, foi acrescida de um regime de execução penal diferenciado capaz de isolar alguém por até 720 dias. E isso tudo em um governo de esquerda cuja base aliada no Congresso era, ao tempo da votação, amplamente majoritária." (Rolin, 2006, p.14).

${ }^{19}$ Nesse ponto é ilustrativo que o leitor leia a entrevista do governador dada ao jornal Estadão, e disponibilizada pelo jornal Opovo em 01 de novembro de 2018, cujo link consta na bibliografia.

20 "The symbolic figure of the victim has taken on a life of its own, and plays a key role in political and policy argument. The crime victim is no longer represented as an unfortunate citizen who has been on the receiving end of a criminal harm. His or her concerns are no longer subsumed within 'the public interest' that guides prosecution and penal decisions. Instead, the crime victim is now, in a certain sense, a representative character whose experience is assumed to be common and collective, rather than individual and atypical." (GARLAND, 2001, p. 144).

${ }^{21}$ Traduzido livremente do trecho: “A zero-sum policy game is assumed wherein the offender's gain is the victim's loss, and being 'for' victims automaticlly means being tough on offenders."
} 
bandeira, defender o estado democrático de direito contra ameaças internas e externas.

Usarei todos os meios e conhecimentos para derrotar o crime organizado, reconstruindo, reaparelhando, aperfeiçoando o processo penal e as estruturas judiciais, treinando as nossas forças policiais, colocando à disposição profissionais da segurança capacitados e com instrumentos para conter a ameaça à nossa democracia.

São narcoterroristas e como terroristas serão tratados!

A mudança da nossa estrutura de segurança é fundamental para aproximar as instituições que compõem todo o processo criminal, sendo a atividade policial apenas parte de um gigantesco leque de aparato de punição e de ressocialização. (Discurso de Wilson Witzel ao ser empossado governador do RJ, 2019)

Conforme PRATT (2007), o discurso do populismo penal requer e incentiva um envolvimento emocional muito maior de seus ouvintes do que uma análise racional. A experiência pessoal anedótica se torna nesse ponto fundamental para a compreensão do fenômeno do crime ${ }^{22}$, encobrindo e superando quaisquer argumentos científicos ou análises a partir de fatos. O 'sentir' se torna fundamental em uma retórica oficial punitivista. Sinais externos de poder e punição se tornam, portando, fundamentais. Quando o governador do Rio aparece empunhando uma metralhadora e diz querer mostrar o poderio bélico dos agentes da polícia, conforme matéria do jornal Extra do dia 04 de abril de 2019, ou publica um vídeo em suas redes sociais onde sobrevoa favelas em um helicóptero em companhia de agentes policiais pesadamente armados e afirma que vai "dar um fim na bandidagem", conforme matéria do jornal Folha de São Paulo de 8 de abril de 2019, ele não apenas torna pública sua postura como político partidário de medidas punitivistas, mas também ressignifica seu discurso, elevando-o à radicalidade. Quando ele diz em seu discurso de posse que os criminosos de seu estado serão tratados de forma comparável à 'terroristas', ele não mais que dizer (como talvez preteritamente poderia ser entendido) que eles serão apenas tratados com rigor, mas que eles potencialmente (senão certamente) serão exterminados sumariamente. $\mathrm{O}$ populismo penal perde aqui sua sutileza e se mostra em sua face mais brutal e triunfante, enquanto uma violência gráfica se infiltra progressivamente em sua linguagem.

\section{CONCLUSÃO}

É possível concluir, assim, que a linguagem punitiva do populismo penal é profundamente infiltrada pelas tensões e frustrações políticas vivenciadas pela sociedade hodierna. A linguagem punitiva não é apenas uma mera instrumentalização do discurso para

\footnotetext{
22 “(...)In these respects, anecdote and personal experience are better able to convey the authenticity of crime experiences than mere statistics. As a result, populist debate about crime and punishment revolves more around the emotion that such representations invoke rather than rational, considered judgement.(...)". (PRATT, 2007, p. $14)$.
} 
fins políticos, mas sim a expressão de uma crise de confiança de caráter estrutural quanto às instituições democráticas. Em uma república onde se fragiliza a compreensão do Estado como um Estado Democrático de Direito e, portanto, um provedor e garantidor de direitos, e se torna mais comum a crença no mesmo como um Estado exclusivamente voltando para o atendimento dos interesses particulares de alguns de seus agentes, a força e o arbítrio se infiltram cada vez mais no discurso político, especialmente em temas de segurança pública.

\section{REFERÊNCIAS BIBLIOGRÁFICAS}

BARBON, Julia. Helicóptero com Witzel a bordo atirou em lona de oração em Angra, dizem moradores. Folha de São Paulo. 8 de maio de 2019. Disponível em: https://www1.folha.uol.com.br/cotidiano/2 019/05/helicoptero-com-witzel-a-bordoatirou-em-lona-de-oracao-em-angradizem-moradores.shtml. Acesso em: 18 mai. 2019.

FURSTENBERG, Frank F. Jr. Reaction to Crime in the Streets. In: The American Scholar, Vol. 40, No. 4 (1971), p. 601$610 . \quad$ Disponível em: http://www.jstor.org/stable/41209894. Acesso em: 16 abr. 2019.

GARLAND, David. The Culture of Control: Crime and Social Order in Contemporary Society. Chicago: The University of Chicago Press, Chicago, 2001.

GAUCHAZH. Ex-juiz recebeu o cargo das mãos de Torquato Jardim e Raul Jungmann, que comandavam as pastas que ficarão sob seu comando no governo Bolsonaro. 02 de janeiro de 2019. Disponível em: https://gauchazh.clicrbs.com.br/politica/not icia/2019/01/leia-a-integra-do-discurso-deposse-do-ministro-sergio-morocjqff4hxh0oz301rx3nhkkpvn.html. Acesso em: 28 abr. 2020.

GRAY, Emily; JACKSON, Jonathan; FARRAL, Stephen. Feelings and
Functions in the Fear of Crime: Applying a New Approach to Victimisation Insecurity. In: British Journal of Criminology 51(1), 2011. Disponível em: https://www.researchgate.net/publication/4 8909842_Feelings_and_Functions_in_the_ Fear_of_Crime_Applying_a_New_Approa ch_to_Victimisation_Insecurity.Acesso em: 18 mai. 2019.

G1. Veja a íntegra do discurso de Wilson Witzel ao ser empossado governador do RJ. G1 Rio. 01 de janeiro de 2019. Disponível em: https://g1.globo.com/rj/riode-janeiro/noticia/2019/01/01/leia-aintegra-do-discurso-de-wilson-witzel-aoser-empossado-governador.ghtml. Acesso em: 18 mai. 2019.

HUNTER, Wendy; POWER, Timothy J. Bolsonaro and Brazil's illiberal backlash. 2019. Disponível em: https://muse.jhu.edu/article/713723/summa ry. Acesso em: 20 abr. 2020.

INGLEHART, $\mathrm{R}$ et al. World Values Survey: Round Six - Country-Pooled Datafile Version. Madrid: JD Systems Institute; (eds.). 2014. Disponível em: http://www.worldvaluessurvey.org/WVSD ocumentationWV6.jsp. Acesso em: 20 abr. 2020.

JACKSON, Jonathan. Introducing fear of crime to risk research. 2006. Disponível 
em: http://eprints.lse.ac.uk/805/. Acesso em: 12 abr. 2019.

KLEMPERER, Victor. The language of the third reich. Tradução inglesa realizada por BRADY, Martin. London: Bloomsbury Acadmic, 2013.

MOISÉS, José Álvaro; CARNEIRO, Gabriela Piquet. Democracia, Desconfiança Política e Insatisfação com o Regime - O caso do Brasil. In MOISÉS, José Álvaro (org) et al. Democracia e Confiança: Porque os Cidadãos Desconfiam das Instituições Públicas? São Paulo. Editora da Universidade de São Paulo, 2010. p. 149-184.

PANIZZA, Francisco. Populism, Social Democracy and the Tale of 'Two Lefts' in Latin America. In: PANIZZA, Francisco (org) e SPANAKOS, Petros (org). Conceptualising comparative politics. New York: Routledge, 2016.

PLANALTO. Discurso do Presidente da República, Jair Bolsonaro, durante cerimônia de Recebimento da Faixa Presidencial. 01 de janeiro de 2019. Disponível em: http://www2.planalto.gov.br/acompanhe-oplanalto/discursos/2019/discurso-dopresidente-da-republica-jair-bolsonarodurante-cerimonia-de-recebimento-dafaixa-presidencial. Acesso em: 16 mai. 2019.

PLEYSIER, Stephan e COPS, Diderik. Fear of crime as a 'sponge': toward a more dynamic understanding of the relacionship betwen generalized social attitudes and fear of crime. In: Chandee, Derek. Pyschology of Fear, Crime and Media: International Perspectives. New York: Routledge, 2016. p. 3 - 21.

POVO. A polícia vai mirar na cabecinha e... Fogo, afirma Wilson Witzel. 01 de novembro de 2018. Disponível em: https://www.opovo.com.br/noticias/politica /ae/2018/11/a-policia-vai-mirar-nacabecinha-e-fogo-afirma-wilsonwitzel.html. Acesso em: 18 mai. 2019.

PRATT, John. Penal Populism. New York: Routledge, 2007.

ROLIM, Marcos. A Segurança como um desafio moderno aos direitos humanos. $2007 . \quad$ Disponível em: http://library.fes.de/pdffiles/bueros/brasilien/04807.pdf. Acesso em: 11 jun. 2019.

ROSAVALLON, Pierre. Counter Democracy: Politics in a Age of Distrust. Traduzido por Arthur Goldhammer. New York: Cambridge University Press, 2008.

SILVA, Daniel. Enregistering the nation: Bolsonaro populist branding of Brasil. $2019 . \quad$ Disponível em: https://www.academia.edu/39723321/Enre gistering_the_nation_Bolsonaros_populist _branding_of_Brazil. Acesso em: 27 abr. 2020. 
I WANT PICTURES, WHERE ARE THE IMAGES COMMANDER HAMILTON? THE RHETORIC OF CONTEMPORARY CRIMINAL POPULISM AND THE 'DEMOCRACY OF DISTRUST', AN ANALYSIS OF THE IMPACTS OF CRIMINAL POPULISM ON THE CONTEMPORARY BRAZILIAN PUNITIVE COMPLEX

Leonardo Faustino Pereira | Sara Carolina Zica Ribeiro

How to cite this article: PEREIRA, Leonardo Faustino; RIBEIRO, Sara Carolina Zica. Eu quero imagens, cadê as imagens, comandante Hamilton? A retórica do populismo penal contemporâneo e a 'democracia da desconfiança', uma análise dos impactos do populismo penal no contemporâneo complexo punitivo. Revista de Ciências do Estado. Belo Horizonte: v. 5, n. 1, e15166. ISSN: 2525-8036.

\begin{abstract}
Brazilian punitive complex, understood here not only as the prison but as all instances of the exercise of state power in its criminalizing activity, not only exists in the figure of its agents, institutions and physical means of control and containment, but also has existence in the cultural field, infiltrating language and through it the social perception of reality. Thus, it is possible to say that there is a punitive language formed and capable of reforming the punitive complex. However, this language, existing as a social construct, is continually at the mercy of external factors, and the recent escalation of party-ideological sectarization and the emergence of political identities based on distrust in traditional institutions have reshaped this language and ultimately instance the whole punitive complex, towards an ultra-punitivism of strong populist appeal. This paper attempts to understand how contemporary relations between politics and language have led to this phenomenon.
\end{abstract}

Keywords: crime; populism; language. 